European Journal of Sustainable Development Research

2019, 3(1), em0068

ISSN: 2542-4742

\title{
Improving the Eco-Innovation Status of Africa using Sustainable Chemistry Principles
}

\author{
Jude Chidozie Nnaji ${ }^{1 *}$, Augustine Igbuku ${ }^{1}$ \\ ${ }^{1}$ Michael Okpara University of Agriculture, Umuahi-Ikot Ekpene Road, Umuahia Umudike, NIGERIA \\ 2 Shell Petroleum Development Company, NIGERIA
}

*Corresponding Author: judennaji30@gmail.com

Citation: Nnaji, J. C. and Igbuku, A. (2019). Improving the Eco-Innovation Status of Africa using Sustainable Chemistry Principles. European Journal of Sustainable Development Research, 3(1), em0068. https://doi.org/10.20897/ejosdr/3934

Published: February 6, 2019

\begin{abstract}
Sustainable or green Chemistry has been identified as a crucial ingredient for sustainable development due to the vast array of chemical materials and processes that are utilized in the production of goods and services. This study reviews the concepts of sustainability and sustainable development in the context of sustainable chemistry and outlines its principles and benefits while presenting eco-innovation as an important approach to sustainability. The status of African countries in the eco-innovation movement is not encouraging and the continent is largely left out in this endeavour due factors like poor implementation and or domestication of existing eco-innovation policies; lack of eco-innovation policies and indigenous eco-innovations mentality. Areas for the application of sustainable chemistry principles and driving eco-innovations in Africa are highlighted and inherent challenges are analyzed.
\end{abstract}

Keywords: Africa, sustainable chemistry, eco-innovation, development

\section{INTRODUCTION}

Sustainability is the pathway through which humanity can meet current environmental, human health, economic and social needs without compromising the progress and success of future generations (Graedel and Allenby, 1995; WCED, 1987). The sustainability concept has become increasingly important due to indiscriminate natural resource use, environmental pollution, disease and socio-economic conflicts. Consequently, one hears of, sustainable manufacturing, sustainable consumption, sustainable chemistry, sustainable agriculture etc. Figure 1 shows the three pillars of sustainability which will lead to mutual interaction of society and industry for the creation of an equitable society. Each pillar is required to be strong for an activity or process to be sustainable.

Manufacturing activities should seek the reduction of natural resource use, waste generation, carbon footprint and negative impacts on the environment. In addition, activities should be equitable to and consider the needs of all stakeholders (employees, shareholders, customers and society) while being carried out in a profitable manner. Sustainable development refers to the advancement of society within acceptable levels of exploitation of resources, allocation of investments, technological development and organizational change such that due attention is paid to the needs of future generations (Azapagic et al., 2004). World population has grown from about 1 billion in 1800 to about 7.55 billion in 2017 and is estimated to reach 11.18 billion by 2100 . Africa is the fastest growing continent in terms of population with a figure of about 1.2 billion as at 2017 which is $16 \%$ of the global population (UN, 2017). The increasing world population will lead to greater pressure on the fast depleting global natural resource base and result in adverse effects on the environment due to the expected increase in industrial production. 


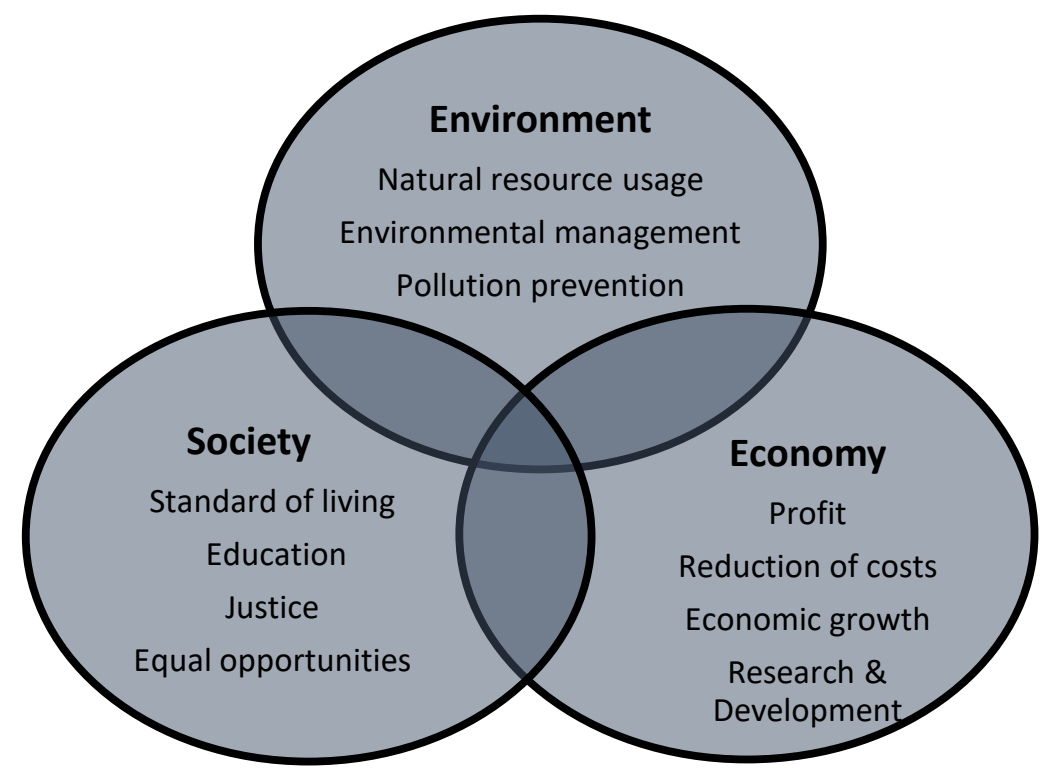

Figure 1. Pillars of Sustainability (Source: IHU, 2015)

The concepts of sustainability and sustainable development are necessary interventions aimed at creating awareness on the present dangers and help humans conduct activities in such a manner that the interest of future generations and the environment are taken into consideration. The United Nations has set 17 Sustainable Development Goals (SDGs) to guide global sustainable development and these goals are supposed to be met by countries by the year 2030. However, the success or otherwise of sustainable development depends on the longterm integration of social, economic and environmental goals by different countries and regions and the adoption of environmentally friendly and efficient methods of production by industries. While regions like Europe and Asia have advanced in eco-innovation activities and are strenuously enacting and modernizing eco-innovation policies, Africa seems to be far behind in this endeavor. This review looks at the principles of sustainable chemistry, sustainable chemistry and eco-innovation, the importance and status of eco-innovations in Africa and enumerates potential areas for applying sustainable chemistry principles in order to drive eco-innovations and sustainable economic development of Africa.

\section{SUSTAINABLE CHEMISTRY}

Sustainable or Green chemistry (also called environmentally benign chemistry) is 'a scientific concept that seeks to improve the efficiency with which natural resources are used to meet human needs for chemical products and services. Sustainable chemistry encompasses the design, manufacture and use of efficient, effective, safe and more environmentally benign chemical products and processes" (OECD, 2018). It advocates the use of materials and processes with the least adverse effects on the environment - human beings, animals, plants and ecosystems. In other words, sustainable chemistry aims at the reduction of waste generation, toxicity of materials, energy consumption, climate change and depletion of natural resources in manufacturing and research activities (Kirchhoff, 2015).

\section{Principles of Sustainable Chemistry}

There are different sets of principles drawn up for sustainable chemistry but the five general principles of sustainable chemistry by OECD/UBA (2004) are adopted for this study:

i. Qualitative development - Use of harmless substances, or where this is impossible, substances involving a low risk for humans and the environment, and manufacturing of long-life products in a resource-saving manner

ii. Quantitative development - Reduction of the consumption of natural resources, which should be renewable wherever possible, avoidance or minimization of emission or introduction of chemicals or pollutants into the environment. Such measures will help to save costs.

iii. Comprehensive life-cycle assessment - Analysis of raw material production, manufacture, processing, use and disposal of chemicals and discarded products in order to reduce the consumption of resources and energy and to avoid the use of dangerous substances 
iv. Action instead of reaction - Avoidance, already at the stage of development and prior to marketing, of chemicals that endanger the environment and human health during their life cycle and make excessive use of the environment as a source or sink; reduction of damage costs and the associated economic risks for enterprises and remediation costs to be covered by the state.

v. Economic innovation - Sustainable chemicals, products and production methods produce confidence in industrial users, private consumers and customers from the public sector and thus, result in competitive advantages.

\section{ECO-INNOVATION}

Eco-innovation is the development of products or processes that contribute to sustainability by reducing the use of natural resources (materials, energy, water and land) and decreasing the release of harmful substances across the whole lifecycle while also offering customer and business value (EIO, 2010; EC, 2018). Eco-innovation is also called 'green-innovation' and it aims at the development of products, processes, skills or new business forms with direct or indirect ecological improvements in order to enhance sustainable development (Jo et al., 2015). It calls attention to the positive contribution that industry can make to sustainable development and a competitive economy (OECD, 2009) which requires deliberate improvements on existing products and processes, creation of new products and processes, combination of processes and materials, discovery of new raw materials, markets and distribution channels are. The three dimensions of eco-innovation are:

a) Targets - the products, processes (e.g. production methods, procedures or marketing methods), organizations or institutions that require improvement i.e. product, process or organizational ecoinnovation may be needed.

b) Mechanisms - the pathway or methods through which change is achieved in the target. It may be modification, re-design, use of alternatives or creation of entirely new products

c) Impacts - the effects of the eco-innovation on the environment across the lifecycle of the target.

Eco-innovations range from simple activities like the use of biodegradable paper instead of non-biodegradable plastic in product packaging to more complex activities like the redesign of industrial processes. Governments, individuals and industries around the world have drawn up eco-innovation strategies to make manufacturing more eco-friendly. Hojnik (2017) categorized types of eco-innovation in a business organization into:
a) Product eco-innovation
b) Process eco-innovation
c) Technological eco-innovation
d) Organizational eco-innovation
e) Marketing eco-innovation
f) Social eco-innovation
g) System eco-innovation

\section{Importance of Eco-innovation}

a) Reduction of natural resource depletion. Man uses more natural resources than the Earth can sustain in the long term. Global resource extraction increased from 26.7 billion tonnes in 1970 to 82.9 billion tonnes in 2014 and is estimated to reach 88.6 billion tonnes by 2017 (IRP, 2017). This will be accompanied by an increase in waste generation and pollution with dire consequences for the environment. Eco-innovations reduce the amount of resources used in the performance of existing processes through increased resource efficiency and increased adoption of a circular economy (efficient infrastructure and product designs, recycling, reuse and remanufacturing) which ultimately translates to the reduction of pressure on natural resources (Moses, 2017).

b) Improvement of environmental quality. The world faces several environmental challenges and ecoinnovation seeks to reduce material use in industrial processes and the use of more environmentally friendly methods in production which will reduce the emission of pollutants like Greenhouse gases (GHGs) that cause climate change.

c) Engenders industrial efficiency and economic development. Eco-friendly innovations are known to foster industrial efficiency and economic development (UNIDO, 2015; Sarkar, 2013; Kohler et al., 2014; Park et al., 2017). It has also led to the formation of eco- industries which provide jobs for the unemployed and make profits for industries. European eco-industries had a turnover of more than $€ 700$ billion in 2013 and provided about 4.2 million jobs in the European Union (EC, 2016).

d) Creation of innovative products and services produced and distributed under fair conditions and sold at fair prices (Bunke, 2016) 
e) Adoption of green methods and processes by manufacturing industries. According to UNEP (2013) green manufacturing entails the 're-design of products, production systems and business models, as well as extended producer responsibility in the form of take-back or reversed supplies, resource efficient and clean production, remanufacturing, and recycling on a significant scale'.

f) Leads to the realization of a green economy and a more equitable society with a mutually beneficial interaction between society and industry.

g) Leads to employment creation and poverty reduction as a result of savings from increased efficiency, implementation of eco-friendly processes and establishment of eco-industries.

\section{Eco-industries}

Eco-Industries comprises of 'all enterprises, including service enterprises, having energy and environment issues as the core source of income' (Dervojeda et al., 2013). This includes small industries involved in renewable energy, waste recycling, environmental auditing and consultancy and capital intensive enterprises involved in pollution management, waste, wastewater and transport. UNEP (2018) defined an inclusive green economy as 'one that improves human well-being and builds social equity while reducing environmental risks and scarcities'. Ecoindustries encourage the growth of a green economy since they strive to improve process efficiency and reduce natural resource depletion, pollution and biodiversity loss. While the eco-industry concept is well recognized in places like the US, Europe and Brazil, it is yet to catch on in most African countries. There are about 250 recognized eco-industrial parks in operation or being developed worldwide but only a few are located in Africa countries (World Bank, 2018a; Alhilali, 2018)

\section{SUSTAINABLE CHEMISTRY AS A DRIVER FOR ECO-INNOVATION}

The chemical industry broadly encompasses companies that employ chemical reactions in the manufacture of a variety of products which includes those involved in the manufacture of basic chemicals, specialty chemicals, fine chemicals, agrochemicals, plastics and fibers, pharmaceuticals, paints and coatings, soaps and detergents etc. The vast majority of manufacturing industries also employ chemical materials and processes leading to the generation of wastes. Manufacturing industries in general, have contributed immensely to the socio-economic and political growth of the society through the provision of critical products and services and generation of income and employment. For instance, the chemical industry, which is a sub-set of manufacturing industries, had a global turnover of $€ 3.360$ billion in 2016 (CEFIC, 2018). However, the chemical and manufacturing industries have also caused significant damage to the society through disasters and damage to the environment. The adverse impacts of pollution from the chemical and manufacturing industries have resulted in research into eco-friendly (greener or cleaner) production technologies which aim to reduce these impacts. This requires the use of sustainable chemistry principles, equipment and chemicals that are both efficient and eco-friendly. Eco-innovations in all forms are being encouraged in chemical and manufacturing industries which will ultimately reduce the pressure on natural resources, reduce pollution and lead to the creation of circular economies. For instance, the Spanish Footwear Institute, INESCOP has developed the oxazolidine tanning technology for the manufacture of a more eco-friendly leather which is similar in appearance, quality, properties and applications to leather obtained using the conventional tanning process. The new process significantly reduces the environmental impact of the conventional process since the leather, wastewater and wastes are chromium-free (Swithmed, 2018).

\section{STATUS OF ECO-INNOVATION IN AFRICA}

Africa is the second largest continent in the world both in size and population and consists of 54 countries at different stages of social and economic development. The gross domestic product (GDP) of sub-Saharan Africa was estimated at $2.7 \%$ in 2017 while economic growth rate is projected to be $3.1 \%$ in 2018 compared to $3 \%$ for Middle East/North Africa and 5.4 for East Asia/the Pacific excluding China (World Bank, 2018b). African countries, of which Nigeria is a prominent example, seem to be far behind in the eco-innovation movement. According to (Stamm, 2013), a prominent indicator of innovative capacities in countries is the gross expenditure on research and development (GERD) to gross domestic product (GDP) ratio (the GERD/GDP ratio). A study of GERD/GDP ratio of developed and developing countries showed that only one African country, Tunisia performed above the 1\% level. No African country is among the top 25 innovative countries on the Global Innovation Index (GII) of 2016 (Cornell University/INSEAD/WIPO, 2016). This scenario needs to change since such countries are among the most environmentally less educated and highly polluted areas of the world. South Africa seems to be the only African country with a well-defined eco-innovation policy and it is taking determined steps to entrench the eco-innovative mentality in manufacturing enterprises. South Africa was the only country 
mentioned in the European innovation Scoreboard and it was adjudged a modest innovator relative to the EU (Moses, 2017; EU, 2018).

The African Union formulated the 10-year Science, Technology and Innovation Strategy for Africa (STISA2024) in 2014 and some African countries and regional groups have also adopted similar policies (AU Commission, 2014; Moses, 2017; Osakwe and Moussa, 2017). However, the STISA-2024 document does not include ecoinnovation and has only one priority area that has an environmental component which on focuses on environmental protection including climate change studies. A much needed approach is for all African countries to appreciate the importance of eco-innovations and make determined efforts to initiate and implement policies that will drive it. Countries in Africa need to be eco-innovators rather than copiers of eco-innovations. History has shown that indigenous technological innovations have a better chance of driving a country's techno-economic and social advancement compared to copying already established technologies. Environmental policy drives ecoinnovation in developed countries (Jo et al., 2015; EEA, 2014) and it is crucial for African countries to fully establish, domesticate and implement similar policies. Policy implementation in the form of incentives, regulations and assistance is the bedrock for successful eco-innovations as confirmed by the scenario in other countries and regions like the European Union and Asia (Bossle et al., 2016; Szutowski et al., 2017).

The future market for sustainability technologies, in general, is huge and will depend on increasing application of eco-innovations (Kohler et al., 2014). While this statement is true, it can only fully materialize if governments establish and implement adequate mechanisms and regulations to guide and encourage eco-innovations. However, adequate focus should be given to the indigenous creation of eco-innovation in existing international policies so that developing countries can be producers rather than consumers of eco-innovations (Jauhiainen and Hooli, 2017).

\section{AREAS FOR APPLYING SUSTAINABLE CHEMISTRY AND DRIVING ECO- INNOVATIONS IN AFRICA}

Areas for application of sustainable chemistry based eco-innovations in Africa include:

a) Purification of source water for potable water production

(i) Use of biomaterials (e.g. Garcinia kola and Carica papaya seeds) for water treatment

(ii) Use of graphene for water filtration

(iii) Methodologies for water recycling and reduction of water consumption in industry and homes

b) Power and Renewable energy. About $40 \%$ of global GHG emission is attributed to the power sector (ICCA, 2017) and it becomes crucial that technologies producing less GHGs and those using renewable energy sources are utilized in power production.

(i) Production of biogas from biomass, kitchen and other wastes

(ii) Production of biodiesel from waste cooking oil (WCO)

(iii) Production of biodiesel from algae

(iv) Solar powered cookers, refrigerators and air-conditioners

(v) Harnessing wind, hydrokinetic and geothermal energy

(vi) Production of electric cars and biofuel based vehicles

(vii) Cleaner burning cook stoves (Shell, 2016)

c) Waste reduction, management and recycling

Effluent reduction and treatment strategies

(i) Techniques for the recycling and disposal of e-waste

(ii) Recycling of wastes from one industry for use in another e.g. Harvesting of nitrogen and phosphorus from organic effluents

(iii) Recycling of waste materials into useful products:

- Conversion of waste paper into paper bags, toilet paper etc;

- Conversion of aluminium cans into products. Aluminium recycling saves money and reduces life cycle impacts

- Plastics. Plastics can also be converted into crude oil or gaseous fuels by heating to high temperatures (pyrolysis). This is also an expensive process and research into cheaper ways of recycling plastics is needed. There is increasing global interest in waste-to-energy systems utilizing waste plastics as feedstock for electricity generation.

- Cost-effective and efficient conversion of scrap metal into useful products on a small scale

- Conversion of organic wastes into fertilizers 
- Extraction of chemicals from food waste. Balu et al. (2012) described a scheme for lowtemperature microwave hydrothermal processing of orange peel which led to the extraction of important products like pectin, bio-oil and sugars. Ayeni (2015) noted sustainable chemistry methods for converting wastes like municipal solid waste, sewage sludge, plastics and agricultural residues into useful products like hydrogen, ethanol and acetic acid

d) Agriculture

- Recycling of e-waste

(i) Biofertilizer production from organic wastes. Unnisa (2015) described a protocol for converting food waste into liquid fertilizer while natural fertilizers are made from water hyacinths in Burkina Faso. There is a whole gamut of organic wastes that can be used for making organic fertilizers and this is a potentially lucrative market for entrepreneurs which will reduce the overwhelming reliance on chemical fertilizers.

(ii) Biopesticides to replace the hazardous synthetic pesticides that are widely used in Nigeria. Ubuoh (2016) advocated for the production and use of biofertilizers and biopesticides as a way of eliminating the environmental impacts of the chemical alternatives.

e) Resource and energy efficiency in industries

(i) New enzymes and catalysts for the vast array of chemical processes

(ii) Adoption of sustainable chemistry principles by industries

(iii) Boosting energy and resource efficient technologies and procedures in industry

(iv) Designing of chemical reaction pathways that minimize energy input (Varma, 2014)

f) Food processing systems

(i) Design of an efficient and affordable natural gas or renewable energy powered animal singeing system for abattoirs to eliminate the use of rubber tyres, plastics and wood which generate GHGs and puts consumers at risk

g) Institutional

(i) Formation of eco-innovation and equitable research groups in HE Institutions

(ii) Formation of eco-innovation platforms by industry. For instance, The Japan Chemical Innovation Institute (JCII) is funded by academic institutions, learned societies and industries in order to engender collaborations among these entities for the sustainable development of the Japanese society.

(iii) Eco-innovation policies by government

(iv) Eco-innovation advocacy by youth groups, Non-Governmental Organizations (NGOs) and Civil Society Organizations (CSOs)

h) Production of biodegradable food containers, shopping bags and sachet. Nippon Ltd., Japan developed bioplastics from renewable biomass like starch and polylactic acid from plants which very similar to traditional plastics but were cheaper, more durable and biodegradable

i) Extractive industries. Africa is a resource-rich continent and instead of utilizing this endowment to advance into production economies, most Africa countries are still natural resource dependent economies (Adewumi, 2013). According to UNDP (2014), resource-dependent economies score lower on the human development index than countries that are less endowed resource-wise but who have production based economies. The solid minerals mining sector in many African countries is still dominated by artisanal small-scale miners who use rudimentary and environmentally hazardous methods like amalgamation with mercury for extracting gold (Nnaji and Amako, 2016). This is an area that calls for eco-innovations that will be affordable to artisanal miners to not only improve efficiency but to also reduce environmental impacts.

j) Production of Eco-friendly materials for the construction industry. Chemical pollutants from paints, solvents, plastics and composite timbers in buildings cause medical conditions like asthma, fatigue and headaches. The goals of eco-friendly construction is pollution minimization and reduction of dependence on logging (which fuels deforestation and biodiversity loss) and power plants (CIC, 2016). Africa is a large construction site and eco-innovations are needed to minimize the negative impacts of construction activities on humans and the environment. This might be in form of resource efficiency, use of ecomaterials (Figure 2) and pollution reduction and mitigation strategies. For instance, research and development is needed in the production of eco-friendly paints which contain less volatile organic compounds (VOCs) and non-toxic pigments but with similar or better performance compared to existing paints. 


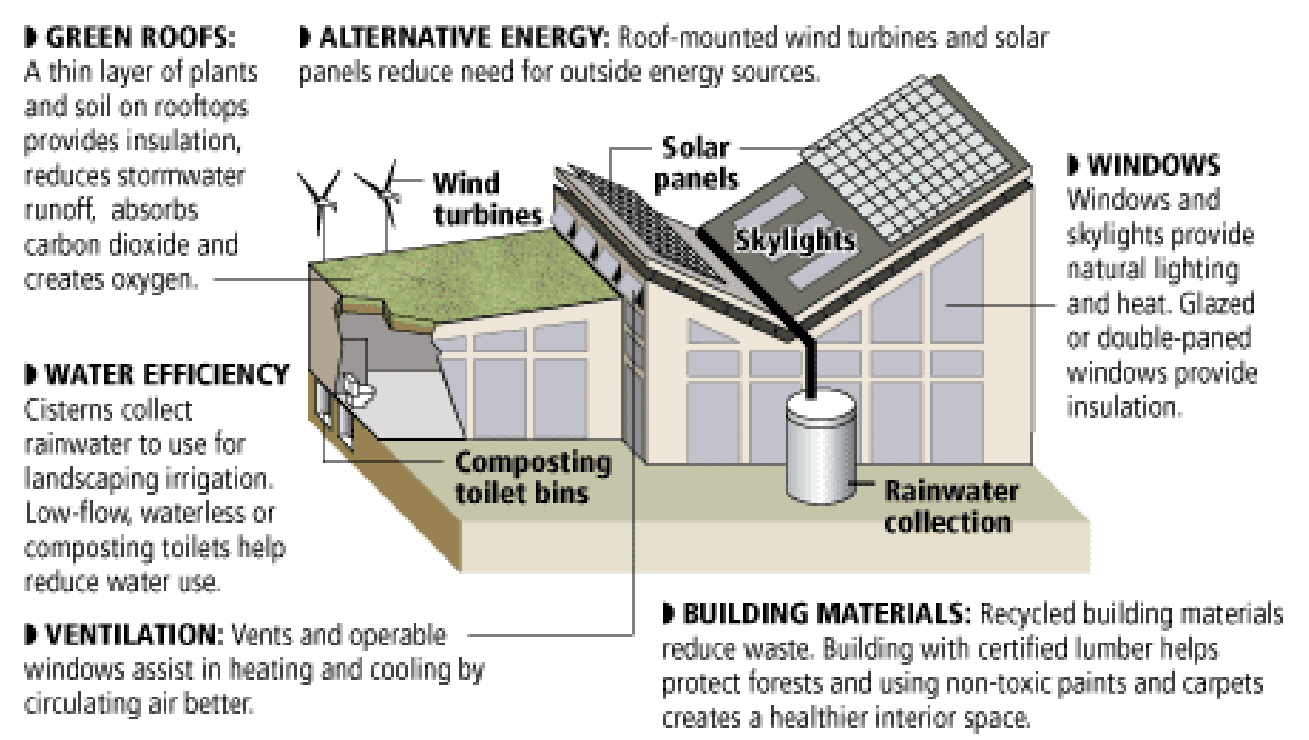

Figure 2. Eco-friendly building (Source: http:// cic.org.uk/admin/resources/g2-w640.png)

\section{CHALLENGES AGAINST SUSTAINABLE CHEMISTRY BASED ECO-INNOVATIONS IN AFRICA}
a) Low awareness of sustainable chemistry and eco-innovation
b) Inadequate domestication, establishment and implementation of government policies and mechanisms on eco-innovation
c) Inadequate implementation of existing laws and regulations on chemicals and other hazardous substances
d) Inefficient energy, transportation and waste management systems
e) Unfriendly financing climate which doesn't encourage innovations
f) Inadequate information sharing and collaborative activities in academia and industry

\section{CONCLUSION}

Eco-innovation in all facets of human activity is a sure path to sustainable development and any country or region that does not embrace it will loose out in terms of good quality environment and socio-economic development. There is currently low eco-innovations generation and uptake in Africa which needs to change if the continent is to progress. Sustainable chemistry principles can be applied in several areas in order to increase the eco-innovation status of Africa. This calls for determined efforts by all stakeholders (governments, academia, industry, non-governmental organization and civil society organizations) so that the well-being of present and future generations will be guaranteed.

\section{REFERENCES}

Adewumi, J. O. (2013). Governance in the Nigerian Extractive Industries: from a human development perspective. LLM Thesis, School of Law, Loyola University, Chicago.

AU Commission. (2014). Science, Technology and Innovation Strategy for Africa 2024. Addis Ababa: African Union Commission.

Alhilali, S. (2017). Development of international standardized approach for Eco-Industrial Parks. International Conference on Sustainable Industrial Areas.

American Chemical Society. (2018). Research Topics in Green Chemistry \& Engineering. Available at: https://www.acs.org/content/acs/en/greenchemistry/research-innovation/research-topics.html (Accessed 10 February 2018)

Ayeni, J. I. (2015). Application of Green Chemistry for Sustainable Development in Nigeria. Journal of Research Development, 24(2), 1-7.

Azapagic, A., Perdan, S. and Cliff, R. (2004). Sustainable Development in Practice: Case Studies for Engineers and Scientists. Chichester: John Wiley and Sons. https://doi.org/10.1002/0470014202 
Balu, A. M., Budarin, V., Shuttleworth, P. S., Pfaltzgraff, L. A., Waldron, K., Luque, R. and Clark, J. H. (2012). Valorisation of Orange Peel Residues: Waste to Biochemicals and Nanoporous Materials. Chem Sus Chem, 5(9), 1694-1697. https://doi.org/10.1002/cssc.201200381

Bossle, M., Dutra de Barcellos, M. and Vieira, L. (2016). The drivers for adoption of eco-innovation. Journal of Cleaner Production, 113, 861-872. https://doi.org/10.1016/j.jclepro.2015.11.033

Bunke, D. (2016). Sustainable Chemistry: What is it about? Institute for Applied Ecology, Freiburg, Germany.

CEFIC. (2018). How is the global chemicals industry doing. The European Chemical Industry Council. Available at: http:/ /www.cefic.org/Facts-and-Figures/Chemicals-Industry-Profile/ (Accessed 22 June 2018)

CIC - Construction Industry Council. (2016). The rise of eco-friendly construction. Available at: http:// cic.org.uk/news/article.php?s=2016-03-23-the-rise-of-eco-friendly-construction (Accessed 16 March 2018)

Cornell University, INSEAD and WIPO. (2016). The Global Innovation Index 2016: Winning with Global Innovation. Ithaca, Fontainebleau, and Geneva: Cornell University, INSEAD and WIPO.

Dervojeda, K., Nagtegaal, F., Lengton, M. and Datta, P. (2013). Eco industries: Framework conditions for worldclass clusters in emerging industries. Available at: http:/ /www.clusterobservatory.eu/eco/uploaded/pdf/1381911725803.pdf (Accessed 20 June 2018)

EEA Report 2/2014. (2014). Resource-efficient green economy and EU policies. Copenhagen: European Environment Agency.

European Commission. (2018). How eco-innovations improve environmental performance within and across sectors. Science for Environment Policy, 505, 1.

European Union. (2018). European Innovation Scoreboard 2018. Luxembourg: Publications Office of the European Union.

Eco-innovation Observatory (EIO) Annual Report. (2010). Pathways to a resource-efficient Europe. Available at: www.eco-innovation.eu/index.php?option=com_content\&view=article\&id=200\&Itemid=258 (Accessed 11 March 2018)

European Commision. (2016). Green jobs - a success story in Europe. Available at: https://ec.europa.eu/environment/efe/themes/economics-strategy-and-information/green-jobs-successstory-europe_en (Accessed 21 June 2018)

Federal Environment Agency (UBA)/OECD/ German Federal Institute for Occupational Safety and Health/ German Federal Ministry for the Environment, Nature Conservation and Nuclear Safety. (2004). International Workshop on Sustainable Chemistry - Integrated Management of Chemicals, Products and Processes. Available at: http://www.gdch.de/taetigkeiten/nch/inhalt/jg2004/dessau.pdf (Accessed 10 February 2018)

Graedel, T. E. and Allenby, B. R. (1995). A review of Industrial Ecology. New Jersey: Prentice Hall, Inc.

Hojnik, J. (2017). In Pursuit of Eco-innovation: Drivers and Consequences of Eco-innovation at Firm Level. Primorska: University of Primorska Press. https://doi.org/10.26493/978-961-7023-53-4

ICCA. (2017). Global Chemical Industry contributions to the Sustainable Development Goals. International Council of Chemical Association. Available at: https://www.icca-chem.org/wpcontent/uploads/2017/02/Global-Chemical-Industry-Contributions-to-the-UN-Sustainable-DevelopmentGoals.pdf (Accessed 14 March 2018)

IHU. (2015). Introduction to Sustainable Development: A brief handbook for students by students. Thessaloniki: International Hellenic University.

IRP. (2017). Assessing global resource use: A systems approach to resource efficiency and pollution reduction. $A$ Report of the International Resource Panel. Nairobi: United Nations Environment Programme.

Jauhiainen, J. S. and Hooli, L. (2017). Indigenous Knowledge and Developing Countries' Innovation Systems: The Case of Namibia. International Journal of Innovation Studies, 1(1), 89-106.

Jo, J., Roh. T. W., Kim, S., Youn, Y., Park, M. S., Han, K. J. and Jang, E. K. (2015). Eco-Innovation for Sustainability: Evidence from 49 Countries in Asia and Europe. Sustainability, 7, 16820-16835. https://doi.org/10.3390/su71215849

Kirchhoff, M. M. (2015). The Role of Green Chemistry in Sustainability. Available at: https://www.epa.gov/sites/production/files/2015-10/documents/c15-kirchhoff-p1.pdf (Accessed 19 June 2018)

Kohler, J., Walz, R. and Marscheider-Weidemann, F. (2014). Eco-Innovation in NICs: Conditions for Export Success with an Application to Biofuels in Transport. Journal of Environment and Development, 23(1), 133-159. https://doi.org/10.1177/1070496513516468

Moses, C. (2017). Eco-innovation in South African manufacturing enterprises: Trends and benefits. Human Sciences Research Council (HSRC) of South African Policy Brief. Available at: www.hsrc.ac.za (Accessed 10 March 2018) 
Nnaji, J. C. and Amako, N. F. (2016). Heavy Metal Concentrations in Wastewater, Sediments and Soils of Nassarawa-Kainji Artisinal Gold Ore Processing Area, Nigeria. Journal of the Chemical Society of Nigeria, 41(1), 58 65.

Organization for Economic Cooperation and Development. (2009). Sustainable Manufacturing and Ecoinnovation- Framework, Practices and Measurement: Synthesis Report. Paris: OECD.

Organization for Economic Cooperation and Development. (2011). Eco-innovation policies in South Africa. Available at: https://www.oecd.org/env/consumption-innovation/50452349.pdf (Accessed 15 March 2018)

Organisation for Economic Cooperation and Development. (2018). Sustainable Chemistry Available at: http://www.oecd.org/chemicalsafety/risk-management/sustainablechemistry.htm (Accessed 10 February 2018)

Osakwe, N. O. and Moussa, N. (2017). Innovation, diversification and inclusive development in Africa. UNCTAD Research Paper No. 2 UNCTAD/SER.RP/2017/2. Available at: http://unctad.org/en/PublicationsLibrary/serrp-2017d2_en.pdf (Accessed 15 March 2018)

Park, M. S., Bleischwitz, R., Han, K. J., Jang, E. K. and Joo, J. H. (2017). Eco-Innovation Indices as Tools for Measuring Eco-Innovation. Sustainability, 9, 2206. https://doi.org/10.3390/su9122206

Shell. (2016). Sustainability Report. The Hague: Royal Dutch Shell Plc.

Sarkar, A. N. (2013). Promoting Eco-innovations to Leverage Sustainable Development of Eco-industry and Green Growth. European Journal of Sustainable Development, 2(1), 171-224.

Stamm, A. (2013). Promoting Eco-Innovation Challenges and potential solutions for private sector development. Bonn: Deutsche Gesellschaft für Internationale Zusammenarbeit (GIZ) GmbH.

Szutowski, D., Szulczewska-Remi, A. and Ratajczak, P. (2017). The Efficiency of Eco-Innovation. Systematic Literature Studies. Economic and Environmental Studies, 17(2), 205-219. https://doi.org/10.25167/ees.2017.42.4

Switchmed. (2018). Environmentally friendly oxazolidine-tanned leather. https://www.switchmed.eu/en/documents/big-business-corner/29-solutions/oxatan.pdf (Accessed 22 June 2018)

Ubuoh, E. A. (2016). Green Chemistry: A Panacea for Environmental Sustainability Agriculture in Global Perspective. Global Journal of Pure and Applied Chemistry Research, 4(1), 21-29.

United Nations Development Programme. (2014). Extractive Industries for Sustainable Development. Available at:

http://www.undp.org/content/dam/undp/library/Poverty\%20Reduction/Extractive\%20Industries/Extract ive-Industries-Brochure.pdf (Accessed 16 March 2018)

United Nations. (2017). World Population Prospects: The 2017 Revision. New York: Department of Economic and Social Affairs, United Nations.

United Nations Environment Programme. (2013). Green Economy and Trade: Trends, Challenges and Opportunities. Available at: http://www.unep.org/greeneconomy/GreenEconomyandTrade (Accessed 14 March 2018)

United Nations Environment Programme. (2018). Why does green economy matter?. Available at: https://www.unenvironment.org/explore-topics/green-economy/why-does-green-economy-matter (Accessed 20 June 2018)

UNIDO. (2015). Fostering innovation for inclusive and sustainable industrial development: the role of international cooperation. United Nations Industrial Development Organization, London. https://www.odi.org/sites/odi.org.uk/files/odi-assets/events-presentations/1794.pdf (Accessed 20 June 2018)

Unnisa, S. A. (2015). Liquid Fertilizer from Food Waste - A Sustainable Approach. International Research Journal of Environment Sciences, 4(8), 22-25.

Varma, R. S. (2014). Greener and Sustainable Chemistry. Applied Science, 4, 493-497. https://doi.org/10.3390/app4040493

World Bank. (2018a). Eco-Industrial Parks Emerge as an Effective Approach to Sustainable Growth. Available at: http://www.worldbank.org/en/news/feature/2018/01/23/eco-industrial-parks-emerge-as-an-effectiveapproach-to-sustainable-growth (Accessed 24 June 2018)

World Bank. (2018b). Africa's Pulse, Spring 2018: Analysis of Issues Shaping Africa's Economic Future (April). Washington DC: World Bank. https://doi.org/10.1596/978-1-4648-1291-0

World Commission on Environment and Development (WCED). (1987). Our Common Future. Oxford: Oxford University Press. 